\title{
UVODNA RIJEČ UREDNICE TEMATSKOG BROJA
}

Pravni fakultet Sveučilišta J. J. Strossmyera u Osijeku organizirao je 15. - 16. ožujka 2018. godine međunarodnu doktorsku konferenciju „EU Child”. Konferencija je bila usmjerena predstavljanju rezultata istraživanja mladih znanstvenika, doktoranada i njihovih mentora u području prekograničnog kretanja djece u EU. Organizirana je u okviru aktivnosti Jean Monnet katedre za prekogranično kretanje djeteta u EU (Jean Monnet Chair on Cross-Border Movement of a Child reg. br. 575451-EPP-1-2016-1-HR-EPPJMO-CHAIR) koji je odobrila Europska unija preko Agencije za obrazovanje, audiovizualnu djelatnost i kulturu (engl. Education, Audiovisual and Culture Agency), kroz sredstva predviđena Erasmus + programom, za razdoblje od 1. rujna 2016. do 31. kolovoza 2019. godine.

Jean Monnet katedra za prekogranično kretanje djeteta u EU u osnovi je projekt intenzivne nastavne aktivnosti u brojnim međusobno povezanim pravnim područjima koja se dotiču prekograničnog kretnja djece u EU. Komponentu razvoja novih nastavnih kurikuluma Katedra nadopunjuje paralelnom provedbom brojnih drugih aktivnosti. Organizirala je okrugli stol, kontinuirano organizira webinare i radionice koje dotiču širok raspon polaznika (od učenika i nastavnika osnovnih škola preko studenata, praktičara i opće zainteresirane javnosti) te regionalnog natjecanja studenata prava. Istraživačka komponenta Katedre dotiče, kako profilirane eksperte, tako i mlade znanstvenike. Upravo je ova doktorska konferencija jedan od događaja usmjerenih jačanju komponente izobrazbe mladih doktora znanosti kojim Katedra želi ohrabriti, savjetovati i potaknuti mentoriranje mlađih naraštaja znanstvenika u istraživanju tematike prekograničnog kretanja djece u EU. Stoga je poziv za dostavu sažetaka Katedra potaknula doktorande da samostalno ili uz svoga mentora provedu istraživanje, predstave ga javno na konferenciji te potom pisano kroz znanstveni rad. Prihvaćene teme ujedno su definirale i dvodnevni program konferencije. Znanstvenoj raspravi pridonijeli su svi sudionici. Uz prestižne inozemne i domaće plenarne govornike: profesoricu Thaliju Kruger (Sveučilište Antwerpen), Szeibert Orsolyju (Eötvös Loránd Sveučilište u Budimpešti), Iris Goldner Lang (Sveučilište u Zagrebu) te Sanju Marjanović (Sveučilište u Nišu) na konferenciji je sudjelovalo 18 doktoranata i njihovih mentora iz osam država. U ovom tematskom broju Pravnog vjesnika objavljuju se samo radovi doktoranada (i mentora) koji su dvostrukom slijepom recenzijom dobili znanstvenu kategorizaciju.

Ivana Rešetar Čulo posvetila je istraživanje aktualnoj problematici Nasilja nad djecom i integriranim sustavima za zaštitu djece u Europskoj uniji. U skladu s međunarodnim i europskim instrumentima i standardima za zaštitu ljudskih prava, države članice Europske unije su obvezne zaštiti djecu od svih oblika nasilja. Uspostava holističkog sustava za zaštitu djece ujedno je glavna obveza svake države članice Europske unije i preduvjet za učinkovitu zaštitu djece. Integrirani sustav za zaštitu djece obuhvaća širok raspon sveobuhvatnih i integriranih mjera te uključuje multidisciplinarnu, međusektorsku i međuagencijsku suradnju svih sudionika. Uslijed migracija u Europsku uniju i mobilnosti unutar Europske unije, broj prekograničnih i transnacionalnih situacija za zaštitu djece raste. Te situacije zahtijevaju suradnju između ustanova socijalne skrbi te pravosudnih, istražnih i drugih tijela u različitim državama članicama Europske unije. U radu se daje prikaz zakonodavstva i politika Europske unije relevantnih za zaštitu djece, te analizira uloga Europske unije u jačanju zaštite djece od nasilja. 
Mirela Župan, Martina Drventić i Senija Ledić su svoj rad posvetile tematici Privremenih mjera i postupcima otmice djece. Autorice ovdje prezentiraju dio istraživanja provedenog u okvirima IZIP projekta „Prekogranično odvođenje i zadržavanje djece - hrvatska praksa i europska očekivanja“. Apliciranjem kvalitativnih metoda u pravnoj znanosti autorice su izdvojile poteškoće s kojima se susreću sudovi u Republici Hrvatskoj. One propitkuju međunarodni i europski sustav za postupanje u slučajevima međunarodne otmice djece, a kako ga utvrđuje Haška konvencija o otmici djece i Uredba Brussels II bis. Iako je prevladavajuće načelo oba instrumenta žurni povratak djeteta u državu članicu iz koje je protupravno odvedeno, postupak povratka i predaje djeteta mora osigurati punu zaštitu djeteta kako u državi nezakonitog boravišta tako i u državi u koju se dijete treba vratiti. Nadležnim tijelima u tim okolnostima na raspolaganju stoje pravni mehanizmi privremenih i zaštitnih mjera predviđeni Uredbom Brussels IIbis te Haškom konvencijom o mjerama za zaštitu djece. Mogućnost poduzimanja takvih mjera ovisit će o nacionalnom pravu države i o posebnim okolnostima slučaja. Autorice ovim istraživanjem donose kako pravni okvir za izricanje privremenih mjera u slučajevima prekogranične otmice, tako i praksu Suda pravde Europske unije. Recepcija globalnih i europskih standarda u hrvatskim je prilikama ipak otežana, što autorice potvrđuju relevantnom nacionalnom sudskom praksom. Argumentirane smjernice pravilnoj primjeni postojećeg okvira čine posebnu vrijednost ovoga rada koji doprinosi kako razvoju pravne znanosti, tako i primjerenom razvoju sudske prakse.

Jane Diala obradom teme Dijete u djetetu: Dječji brak i izgubljeni identitet u Južnoj Africi otvara višeslojni pravni, kulturni i ideološki problem dječjeg braka na afričkom kontinentu. Autorica naglašava kako su u zajednicama subsaharske Afrike vidljive bitne razlike u zakonskim definicijama dječjeg braka, što dječji brak stavlja u širok diskurs kršenja ljudskih prava, ali i uobičajenog prakticiranja maloljetničkih brakova. Autorica propitkuje položaj djeteta koje od djetinjstva i zaštite i skrbi svojih roditelja preuzima zaštitnika i odgojitelja svoje djece. Temeljem opažanja tijekom terenskog rada u južnoafričkim zemljama i literature o kulturnom relativizmu, ovaj rad sugerira da se sukob između kulturne autonomije i zabrane dječjeg braka najbolje rješava kroz pravnu pluralističku perspektivu. Ova perspektiva nastoji premostiti jaz između običajnog prava, nacionalnih zakona i međunarodnim sporazuma. Ona ujedno iziskuje senzibilitet za ekonomske i sociokulturne čimbenike koji stoje iza upornog prakticiranja dječjih brakova.

Pravni fakultet u Osijeku počašćen je organizacijom ovog događaja kao i publikacijama koje su ga slijedile, te se nadamo da će se suradnja sa sudionicima nastaviti. Autori, čiji su radovi objavljeni u ovome tematskom broju, ukazali su na aktualne nove tendencije u različitim područjima prekograničnog kretanja djeteta u EU. Na taj su način doprinijeli proučavanju ovih tema. Kako bi zainteresirana javnost imala puni uvid u radove izložne na konferenciji, radovi svih doktoranada i njihovih mentora bit će objavljeni u zborniku radova s međunarodnom recenzijom, javno dostupnom na internetskoj stranici Jean Monnet katedre https://www.pravos.unios.hr/chair-euchild/euchild-international-doctoral-conference-eu-dijete-medunarodna-doktorska-konferencija. Aktivnosti ove Jean Monnet katedre govore u prilog sustavnog i temeljitog izučavanja pitanja zaštite prava djece i obitelji na Sveučilištu u Osijeku. Vjerujemo da će ovi, ali i ostali rezultati projekta, osigurati bazu za daljnju edukaciju-kako studenata svih razina, tako i šire zainteresirane stručne i ine javnosti, te će služiti kao potvrda znanstvene kompetitivnosti našega Sveučilišta. 